\title{
KEBERADAAN PIDANA MATI DALAM KITAB UNDANG-UNDANG HUKUM PIDANA (KUHP)
}

\author{
Ni Komang Ratih Kumala Dewi \\ Universitas Mahasarawati Denpasar \\ Email : Ratih_Kumala2001@yahoo.co.id
}

\begin{abstract}
Abstrak
Pidana mati merupakan pidana terberat dan sulit untuk diterapkan dalam suatu Negara hukum mengingat pidana mati merupakan salah satu tindakan pelanggaran HAM, namun untuk membuat seseorang mengurungkan niatnya melakukan suatu kejahatan perlu adanya aturan atau hukuman yang dapat memberikan efek jera dan memberikan rasa aman bagi masyarakat dari segala bentuk kejahatan. Tujuan penulisan diarahkan untuk mengetahui Pengaturan Pidana Mati di dalam Kitab Undang-Undang Hukum Pidana yaitu dimana diatur dalam beberapa pasal dalam KUHP dan Keberdaan pidana mati dalam sistem hukum di Indonesia di tinjau dalam perspektif HAM yaitu tentu akan bertentangan dengan HAM khususnya hak untuk hidup, Namun pidana mati diperlukan pula sebagai upaya mencegah terjadinya kejahatan -kejahatan khususnya yang tergolong berat.
\end{abstract}

Kata kunci : Tindak Pidana, Pidana Mati, HAM

\section{Abstract}

Capital punishment is the heaviest crime and difficult to apply in a country of law considering the death penalty is one of the acts of human rights violations, but to make someone discourage of committing a crime there needs to be rules or penalties that can provide a deterrent effect and provide security for the community from all form of crime. The purpose of writing is directed to find out the regulation of the Death Penalty in the Criminal Law Code which is stipulated in several articles in the Criminal Code and the existence of capital punishment in the legal system in Indonesia in terms of human rights perspective, which of course would be contrary to human rights, especially the right to life, however capital punishment is also needed as an effort to prevent the occurrence of crimes, especially those classified as serious

Keywords: Criminal Acts, Death Penalty, Human Rights

\section{Pendahuluan}

Kejahatan merupakan masalah kemanusiaan yang merupakan masalah sosial, tidak hanya merupakan masalah bagi masyarakat tertentu, tetapi juga menjadi masalah yang dihadapi oleh seluruh masyarakat di dunia. Kejahatan merupakan bentuk dari prilaku menyimpang, Perilaku menyimpang 
itu merupakan suatu ancaman yang nyata atau ancaman terhadap normanorma sosial yang mendasari kehidupan atau keteraturan sosial, dapat menimbulkan ketegangan individual maupun keteganganketegangan sosial. Kejahatan adalah masalah manusia yang berupa kenyataan sosial yang sebabmusababnya kurang kita pahami dan terjadi dimana serta kapan saja dalam pergaulan hidup (Prodjohamidjojo, 1997). Kasus-kasus kejahatan disejumlah wilayah tanah air yang menimbulkan berbagai dampak terhadap suatu lingkungan masyarakat seperti kita ketahui dengan majunya zaman saat ini membuat kejahatan semakin berkembang jenisnya seperti kejahatan teknologi, kemanusian dan lain-lainnya.

Setiap bentuk kejahatan yang terjadi tentunya menimbulkan akibat dari suatu perbuatan, akibat yang di peroleh seseorang dari perbuatan yang dilakukan tentunya disesuaikan dengan jenis perbuatannya. Mengingat Indonesia merupakan Negara hukum seperti yang tercantum dalam Undang - undang Dasar Negara Republik Indonesia Tahun 1945 Pasal 1 angka 3 maka hukum harus di tegakan demi keadilan. Melihat korban-korban dari kejahatan yang terjadi sangat banyak dan tidak melihat status atau apapun misalnya orang-orang dari kelas menengah kebawah, anak-anak, lansia, maupun pemerintah Negara. Disinilah kita melihat bagaimana penegakan hukum di indonesia terhadap kasus-kasus kejahatan yang terjadi, tidak jarang pelaku kejahatan di hukum dengan hukum mati melihat perbuatan yang dilakukan snagat berat dan merugikan banyak orang. Hukuman mati merupakan pidana yang paling keras dalam sistem pemidanaan. Masalah pemidanaan berhubungan erat dengan kehidupan seseorang dimasyarakat, terutama bila menyangkut kepentingan benda hukum yang paling berharga bagi kehidupan bermasyarakat yaitu nyawa dan kemerdekaan atau kebebasan. Hukuman mati merupakan pidana yang paling keras dalam sistem pemidanaan. Masalah pemidanaan berhubungan erat dengan kehidupan seseorang dimasyarakat, terutama bila menyangkut kepentingan benda hukum yang paling berharga bagi kehidupan bermasyarakat yaitu nyawa dan kemerdekaan atau kebebasan.

Di tinjauan sosiologis tentu ada pro dan kontra di dalam pemberian hukuman mati karena hukuman mati itu dianggap bertentangan dengan Undang-Undang No.39 tahun 1999 tentang HAM yang juga mengatur bahwa tidak seorang pun boleh ditangkap, ditahan atau dibatasi kebebasannya, dan tidak seorangpun dapat dihukum dengan suatu peraturan yang berlaku surut serta masih banyak hak-hak dasar lain yang harus dijamin, dilindungi dan ditegakkan oleh negara. Di indonesia delik yang diancam dengan pidana mati semakin banyak diatur dalam 
KUHP, eksistensi lembaga pidana mati ditunagkan dalam KUHP secara terperinci menyatakan bahwa sebagaimana diatur dalam Pasal 10 KUHP.

Berdasarkan uraian Pasal 10 KUHP tersebut dapatlah diketahui bahwa lembaga pidana mati merupakan salah satu hukuman yang masih jelas keberadaannya sebagai bagian dari hukuman pidana yang dijatuhkan. Pengaturan tentang penjatuhan hukuman mati masih menimbulkan perdebatan,terutama mengenai pemberlakuan hukuman mati. Perdebatan itu tetap muncul, khususnya antara negara yang telah menghapus hukuman mati dan negara yang memberlakukan hukuman mati. Pihak yang pro hukuman mati menyatakan bahwa, hukuman mati masih dibutuhkan untuk kasus-kasus hukum berat yang dapat mengancam hak asasi orang lain. Sebaliknya pihak yang kontra terhadap hukuman mati menyatakan bahwa, hukuman mati merupakan hukuman yang kejam, tidak manusiawi dan merupakan pelanggaran terhadap hak asasi manusia.

Pro dan kontra mengenai pidana mati bukan merupakan suatu pertentangan yang baru di tengahtengah masyarakat dan para ahli hukum namun sudah terjadi sejak dahulu. Pidana mati hanya merupakan alasan bagi penguasa Negara sebagai alat penegak untuk mempertahankan tertib hukum dalam pemberantasan penjahatpenjahat. Pelaksanaan hukuman mati di Indonesia menjadi bahan pembicaraan yang cukup aktual dan polemik. Hal ini didasari bahwa penerapan hukuman mati tidak sesuai dengan falsafah negara yang menganut paham Pancasila, yang selalu menjunjung tinggi rasa pri kemanusiaan yang adil dan beradab. Dalam kenyataannya, penerapan hukuman mati apapun alasan dan logikanya tetap dilaksanakan di Indonesia dari berbagai kasus tindak kejahatan yang ada.

Keterkaitan pidana mati dengan hak asasi manusia sangatlah erat, hal ini didasarkan pada suatu alasan bahwasanya penjatuhan pidana mati terkait erat dengan hak yang paling asasi bagi manusia. Menurut Undang -undang No 39 Tahun 1999 yang dimaksud dengan hak asasi manusia sebagaimana diatur dalam Pasal 1 yang berbunyi yaitu hak asasi manusia adalah seperangkat hak yang melekat pada hakikat dan keberadaan manusia sebagai makhluk Tuhan Yang Maha Esa dan merupakan anugerah-Nya yang wajib dihormati, dijungjung tinggi dan lindungi oleh negra, hukum dan pemerintah dan setiap orang demi kehormatan serta perlindungan harkat dan martabat manusia. Setiap hak asasi manusia seseorang menimbulkan kewajiban dasar dan tanggung jawab untuk menghormati hak asasi orang lain secara timbal balik serta menjadi tugas pemerintah untuk menghormati, melindungi, menegakkan dan memajukannya. Di dalam Undang- Undang Dasar 
Negara Republik Indonesia 1945 sebagai konstitusi Indonesia, terdapat rumusan-rumusan tentang hak asasi manusia. Hal itu dapat ditemukan dalam pembukaan maupun dalam batang tubuh, dengan adanya rumusan tersebut berarti negara Indonesia mengakui adanya prinsip perlindungan terhadap hak asasi manusia (Sujatmoko, 2007). Namun jika dilihat dari segi tinjauan sosiologis banyak pendapat-pendapat yang menyatakan bahwa hukuman mati tidak pantas diberikan karena melanggar HAM dan ada pula yang beranggapan bahwa hukuman mati pantas diberikan bagi pelaku yang melakukan kejahatan bera. Hukuman mati adalah suatu hukuman atau vonis yang dijatuhkan pengadilan (atau tanpa pengadilan) sebagai bentuk hukuman terberat yang dijatuhkan atas seseorang akibat perbuatannya. oleh sebab itu sangat menarik untuk membahas penelitian mengenai “KEBERADAAN PIDANA MATI DALAM KITAB UNDANGUNDANG HUKUM PIDANA (KUHP) “.

\section{Rumusan Masalah}

1. Pengaturan Pidana Mati di dalam Kitab Undang-Undang Hukum Pidana?

2. Keberdaan pidana mati dalam sistem hukum di Indonesia di tinjau dalam perspektif HAM ?

\section{Pengaturan Pidana Mati di dalam Kitab Undang-Undang Hukum Pidana}

Pidana mati didefinisikan
sebagai suatu nestapa atau
penyiksaan yang memberikan
penderitaan kepada manusia dan
melanggar norma-norma yang
bertentangan dengan kehidupan manusia, dimana antara pidana mati sangat berkaitan dengan pidana dan pemidanaan. Secara substansial, hukuman mati itu merupakan salah satu bentuk sanksi yang diberlakukan pada pelanggar hukum, khususnya palanggaran berat. Hukuman mati dikenal dengan suatu bentuk hukuman yang kejam dan tidak kenal ampun. Sebenarnya tujuan dari pidana itu adalah untuk mencegah timbulnya kejahatan dan pelanggaran. Kejahatan-kejahatan yang berat dan pidana mati dalam sejarah hukum pidana adalah merupakan dua komponen permasalahan yang berkaitan erat. Hal ini nampak dalam KUHP Indonesia yang mengancam kejahatan-kejahatan berat dengan pidana mati. Berdasarkan pada ketentuan yang ada pada KUHP menyangkut tentang macam sanksi pidana atau jenis pemidanaan hanya terdapat 2 macam hukuman pidana sebagaimana dijelaskan dalam pasal 10.

Menurut Prof. Roeslan Saleh mengatakan pidana mati adalah suatu upaya yang radikal, untuk meniadakan orang-orang yang tidak bisa diperbaiki lagi, dan dengan adanya pidana mati ini maka hilanglah pula kewajiban untuk memelihara mereka di dalam penjarapenjara yang demikian besar 
biayanya. Begitu pula hilanglah ketakutan-ketakutan kita jika orangorang tersebut melarikan diri dari penjara dan membuat kejahatan kembali dalam masyarakat (Saleh, 1978).

Pidana mati adalah pidana terberat dari semua jenis pidana pokok, sehingga hanya diancamkan terhadap pelaku kejahatan tertentu saja. Sejauh ini perlu tidaknya pidana mati diancamkan terhadap pelaku kejahatan menimbulkan banyak pendapat. Pidana mati sifatnya eksepsional artinya pidana mati itu hanya dijatuhkan hakim apabila benar-benar diperlukan. Bahkan berdasarkan sejarah, ternyata pidana mati sudah dikenal jauh sebelum negara Indonesia terbentuk yaitu pada masa kerajaan-kerajaan. Oleh sebab itu, mengenai pidana mati di Indonesia dilihat dari sejarahnya adalah bukan hal yang asing. Hanya saja mengenai cara pelaksanaanya yang berbeda satu tempat dengan tempat lainnya. Mengenai pengaturan Pidana Mati di dalam Kitab Undang-Undang Hukum Pidana diatur dalam Pasal 10 KUHP pidana terdiri atas :

a. Pidana pokok :

1. pidana mati

2. pidana penjara

3. pidana kurungan

4. pidana denda

5. pidana tutupan

b. Pidana tambahan:

1. pencabutan hak-hak tertentu

2. permapassan barangbarang tertentu
3. pengumuman putusan hakim (Molejatno, 2005).

Pidana mati dijalankan oleh algojo di tempat gantungan dengan menjeratkan tali yang terikat di tiang gantungan pada leher terpidana kemudian menjatuhkan papan tempat terpidana berdir. Berbicara tentang pidana matai sebgaimana diatur dalam KUHP selanjutnya dituangkan dalam beberapa jenis tindak pidana sebagaimana berikut :

a. Makar terhadap Presiden dan Wakil Presiden.

Pasal 104 KUHP : "Makar dengan maksud membunuh Presiden atau wakil Presiden, atau dengan maksud merampas kemerdekaan mereka atau menjadikan mereka tidak mampu memerintah, diancam dengan pidana mati atau pidana penjara seumur hidup atau pidana selama waktu tertentu, paling lama dua puluh tahun.

b.Membujuk negara asing untuk bermusuhan atau berperang. Pasal 111 Ayat (2) KUHP “Jika permusuhan atau perang sungguh terjadi, diancam dengan pidana mati atau pidana penjara seumur hidup atau pidana penjara selama waktu tertentu paling lama dua puluh tahun.

c. Membantu musuh saat perang Pasal 124 Ayat (3) KUHP Pidana mati atau pidana penjara seumur hidup atau selama waktu tertentu paling 
lama dua puluh tahun dijatuhkan jika si pembuat;

1) Memberitahukan atau menyerahkan kepada musuh, menghancurkan atau merusak sesuatu temapat atau pos yang diperkuat atau diduduki, suatu alat penghubung, gudang persediaan perang, atau kas perang ataupun angkatan laut, angkatan darat atau bagian dari padanya; merintangi, mengalang-alangi atau menggagalkan suatu usaha untuk mengenangi air atau bangunn tentara lainnya yang direncanakan atau diselenggarakan untuk menangkis atau menyerang.

2) Menyebabkan atau memperlancar timbulnya hura-hura, pemberontakan atau desersi di kalangan angkatan perang.

d. Makar terhadap Raja atau kepala-kepala negara sahabat dengan direncanakan dan berakibat maut.

Pasal 140 Ayat (3) KUHP Jika makar terhadap nyawa dilakukan dengan rencana serta berakibat maut, diancam dengan pidana mati atau pidana penjara seumur hidup atau pidana penjara, selama waktu tertentu paling lama dua puluh tahun.

a. Pembunuhan berencana

Pasal 340 KUHP : "Barang siapa sengaja dan dengan rencana lebih dahulu merampas nyawa orang lain diancam, karena pembunuhan dengan rencana (moord), dengan pidana mati atau pidana penjara seumur hidup atau selama waktu tertentu, paling lama dua puluh tahun.

b. Pencurian dengan kekerasan yang mengakibatkan luka berat atau mati.

Pasal 365 Ayat (4) KUHP : "Diancam dengan pidana mati atau pidana penjara seumur hidup atau selama waktu tertentu paling lama dua puluh tahun, jika perbuatan mengakibatkan luka berat atau mati dan dilakukan oleh dua orang atau lebih dengan bersekutu, pula disertai oleh salah satu hal yang diterangkan dalam no. 1 dan 3.

c. Pemerasan dengan kekerasan yang mengakibatkan luka berat atau mati. Pasal 368 Ayat (2) KUHP :

“Diancam dengan pidana mati atau pidana penjara seumur hidup atau selama waktu tertentu paling lama dua puluh tahun, jika perbuatan mengakibatkan luka berat atau mati dan dilakukan oleh dua orang atau lebih dengan bersekutu, pula disertai oleh salah satu hal yang diterangkan dalam no. 1 dan 3 .

d. Pembajakan di laut, pesisir dan sungai yang mengakibatkan kematian.

Pasal 444 KUHP :

“Jika perbuatan kekerasan yang diterangkan dalam pasal 


\begin{abstract}
438-441 mengakibatkan seseorang di kapal yang diserang atau seseorang yang diserang itu mati, maka nahkoda, panglima atau pemimpin kapal dan mereka yang turut serta melakukan perbuatan kekerasan, diancam dengan pidana mati, atau pidana penjara selama waktu tertentu paling lama dua puluh tahun.
\end{abstract}

Hukuman mati merupakan sebuah instrumen untuk melindungi masyarakat dan negara baik dalam bentuk preventif maupun represif. Represif di sini bukanlah menjadikan mereka yang diperintah menjadi rentan dan lemah (Selznick, 2007). Tujuan adanya pidana mati sendiri agar masyarakat memperhatikan bahwa pemerintah tidak menghendaki adanya gangguan terhadap ketentraman yang sangat ditakuti oleh umum. Dengan adanya pidana mati maka pelaku kejahatan akan mengurungkan niat untuk melakukan tindak pidana tersebut. Berdasarkan teori pemidanaan dibagi menjadi 3 golongan yaitu :

\section{a. Teori Absolut atau Teori Pembalasan}

Manusia mempunyai perasaan ingin membalas atau ada kecenderungan untuk membalas yang merupakan efek dari suatu gejala sosial yang normal. Pada teori absolut, yang menjadi dasar pijakan teori ini adalah pembalasan. Pembalasan menurut banyak orang dilakukan sebagai alasan untuk mempidana suatu kejahatan. Kepuasan hatilah yang dikejar (Prodjodikoro, 2011). Hal ini berarti bahwa pidana merupakan suatu keharusan atau merupakan hal yang mutlak menyusul terjadinya kejahatan.Pidana tidak mempedulikan apakah akibat-akibat yang timbul dari dijatuhkannya pidana terhadap seseorang. Hal ini karena tujuan pidana ini hanyalah untuk mengejar kepuasan hati dari pihak yang dirugikan untuk membalas orang yang telah melakukan tindak pidana. Hal tersebut sesuai dengan semboyan Hutang pati, nyaur pati; hutang lara, nyaur lara yang berarti pembunuh harus dibunuh, dan penganiaya harus dianiaya (Prodjodikoro, 2011).

\section{b. Teori Relatif atau Teori Tujuan}

Teori relatif ini melihat bahwa penjatuhan pidana bertujuan untuk memperbaiki si penjahat agar menjadi orang yang baik dan tidak akan melakukan kejahatan lagi. Teori relatif ini juga dinamakan sebagai teori tujuan. Menurut teori ini, suatu kejahatan tidak mutlak harus diikuti dengan suatu pidana. Tujuan dari pidana harus diarahkan kepada upaya agar di kemudian hari kejahatan yang telah dilakukan itu tidak terulang lagi (Prodjodikoro, 2011). Penjatuhan pidana menurut teori ini lebih mengutamakan tujuan dari penjatuhan pidana. Pidana ditujukan agar orang takut untuk melakukan suatu pidana dan kejahatan yang telah dilakukan tidak 
terjadi lagi di kemudian hari, dengan kata lain pidana bertujuan untuk memperbaiki penjahat agar menjadi orang yang baik dan tidak melakukan kejahatannya lagi di kemudian hari.

Teori relatif menyebutkan bahwa pidana adalah alat untuk mencegah timbulnya suatu kejahatan, dengan tujuan agar tata tertib masyarakat tetap terpelihara. Pencegahan atau prevensi ini ada dua macam, yaitu prevensi khusus dan prevensi umum. Keduanya berdasarkan bahwa dengan ancaman akan dipidana dan kemudian dijatuhkannya pidana orang akan takut mejalankan kejahatan (Prodjodikoro, 2011). Pada prevensi khusus, hal membuat takut ditujukan kepada si penjahat, sedangkan dalam prevensi umum ditujukan agar para oknum semua juga takut akan menjalankan kejahatan (Prodjodikoro;2011). Wujud dari prevensi khusus adalah pada penjatuhan pidana terhadap orang yang melakukan kejahatan untuk memperbaiki atau membinasakan orang yang berbuat jahat, sedangkan prevensi umum merupakan upaya untuk menakut-nakuti masyarakat melalui penjatuhan pidana yang dilakukan pada prevensi khusus.

\section{c. Teori Gabungan}

Tujuan pidana di samping adanya teori absolut dan teori relatif, muncul juga teori ketiga yang disebut teori gabungan. Teori gabungan ini mengakui adanya unsur "pembalasan" dalam hukum pidana, namun di pihak lain mengakui pula unsur prevensi dan unsur memperbaiki penjahat yang melekat pada tiap pidananya (Prodjodikoro, 2011). Teori gabungan ini merupakan gabungan antara teori absolut dan teori relatif. Menurut Wirjono Prodjodikoro :

Mudah dapat diadakkan sintesis antara dua aliran yang tampak ekstrem atau jauh satu dari yang lain itu. Sekiranya dalam praktek biasanya ada persesuaian pendapat bahwa suatu kejahatan tertentu harus ditanggapi dengan suatu pidana tertentu. Jika hal ini terjadi, maka pidana tertentu itu memberikan kepuasan kepada semua pihak karena merupakan "pembalasan" yang diinginkan oleh teoriteori absolut dan sekaligus memenuhi syarat dari teoriteori relatif ke arah sutau tujuan prevensi atau memperbaiki penjahat (Prodjodikoro, 2011).

Berdasarkan apa yang telah dikemukakan oleh Wirjono Prodjodikoro tersebut, teori gabungan merupakan teori yang didalamnya menggabungkan pemikiran yang terdapat di dalam teori absolut dan teori relatif yaitu yang menjadi dasar dalam penjatuhan pidana adalah untuk pembalasan dan pertahanan tata tertib masyarakat.Keberadaan pidana mati di Indonesia sebenarnya menurut saya tepat diterapkan mengingat pidana mati sendiri diberikan kepada pelaku kejahatan yang merupakan tindak pidana 
kejahatan yang tergolong berat sehingga disini rasa keadilan itu ada terutama bagi keluarga korban dari suatu tindak pidana kejahatan,apalagi mengingat beberapa masyarakat berpikir darah dibalas dengan darah itulah kebanyak orang selalu berpikir terutama dalam pihak yang dirugikan terhadap suatu kejahatan, seperti contoh kasus bom Bali hamper semua keluarga korban meminta keadilan mengingat banyaknya korban yang ditimbulkan dari ledakan bom tersebut, orang-orang yang tidak bersalah menjadi korban dari kejahatan yang dilakukan oleh beberapa otnum yang memiliki kepntingan tersendiri. Keluarga korban meminta keadilan kepada para penegak hukum dan berharap mereka pelaku kejahatan mendapat ganjaran yang setimpal dari kejahatan yang dilakukan sehingga nyaw dibalas dengan nyawa.

Keberdaan pidana mati dalam sistem hukum di Indonesia di tinjau dalam perspektif HAM

Hukuman mati khususnya di Indonesia memang masih menjadi perdebatan semua kalangan halayak mengingat semua orang didunia ini memiliki HAM untuk hidup. Menurut Undang -undang No 39 Tahun 1999 yang dimaksud dengan hak asasi manusia sebagaimana diatur dalam Pasal 1 yang berbunyi yaitu hak asasi manusia adalah seperangkat hak yang melekat pada hakikat dan keberadaan manusia sebagai makhluk Tuhan Yang Maha Esa dan merupakan anugerah-Nya yang wajib dihormati, dijungjung tinggi dan lindungi oleh negra, hukum dan pemerintah dan setiap orang demi kehormatan serta perlindungan harkat dan martabat manusia. Dalam negara Pancasila, pemahaman atas hakhak asasi manusia dipandang penting sesuai yang tercantum dalam sila kedua, yaitu "Kemanusiaan yang adil dan beradab" dengan menempatkan manusia dengan kodrat, harkat dan martabatnya. Pasal 2 UndangUndang No. 39 Tahun 1999 Tentang Hak Asasi Manusi menjelaskan bahwa Negara Indonesia mengakui dan menjunjung tinggi hak asasi manusia dan kebebasan dasar manusia sebagai hak yang secara kodrati melekat dan tidak terpisah dari manusia yang harus dilindungi, dihormati dan ditegakkan demi meningkatkan martabat kemanusiaan, kesejahteraan, kebahagiaan, dan kecerdasan serta keadilan.

Penjatuhan pidana merupakan bagian yang berperan dalam proses pengadilan pidana harus mendasarkan pada perspektif humanistis dan tujuan pidana integratif serta aliran pemidanaan modern yang mengutamakan perlindungan masyarakat. Ada 3 hal yang menjadi titik pembicaraan dalam hukum pidana yaitu tindak pidana, pertanggungjawaban pidana, dan pengenaan pidana. Menjatuhkan pidana terutama pidana mati, harus memperhatikan faktor faktor yang menyangkut HAM terpidana, dan menjadikan pidana bersifat 
oprasional dan fungsional. Penerapkan pidana mati terhadap pelaku kejahatan dengan mengedepankan kriteria tindak pidana yang dilakukan sebagai berikut:

1.Melampaui batas kemanusiaan, 2.Mencelakai dan mengancam banyak manusia,

3. Merusak generasi bangsa,

4. Merusak peradaban bangsa,

5. Merusak tatanan di muka bumi,

6.Merugikan serta menghancurkan perekonomian negara

Walaupun hak untuk hidup dilindungi oleh konstitusi yang dijiwai oleh nilai kemanusiaan dalam Pancasila, tetapi sampai saat ini dalam sistem hukum di Indonesia masih menerapkan hukuman mati dalam sistem pemidanaannya. Jika dikaji lebih mendalam sesuai dengan ketentuan dokumen hak asasi manusia, terdapat beberapa pasal di dalam dokumen hak asasi manusia yang tidak melarang pelaksanaan hukuman mati karena bertentangan dengan hak hidup seseorang. Penerapan hukuman mati digolongkan sebagai bentuk hukuman yang kejam dan tidak manusiawi. Hak asasi manusia berlaku kapanpun, di manapun, dan kepada siapapun, sehingga sifatnya universal. HAM pada prinsipnya tidak dapat dicabut. Hak asasi manusia juga tidak dapat dibagi-bagi, saling berhubungan, dan saling bergantung. Hak asasi manusia biasanya dialamatkan kepada negara, atau dalam kata lain, negaralah yang mengemban kewajiban untuk menghormati, melindungi, dan memenuhi hak asasi manusia. Adanya pidana mati dikaji dalam perspektif HAM tentunya merupakan pelanggaran karena kita merampas hak untuk hidup seseorang mengingat pemberian pidana mati itu tidak sembaranagan tentunya dengan pertimbangan yang matang oleh para penegak hukum. Pidana mati jika dikaitkan dalam perspektif HAM tentu akan bertentangan dengan HAM khususnya hak untuk hidup sebagaimana diatur dalam Undangundang Dasar Negara Republik Indonesia Tahun 1945 dimana diatur dalam Pasal 28A yaitu Setiap orang berhak untuk hidup serta berhak mempertahankan hidup dan kehidupannya dan Undang-Undang No 39 Tahun 1999 Tentang HAM sebagaimana diatur dalam Pasal 4 yaitu menjelaska Hak untuk hidup, hak untuk tidak disiksa, hak kebebasan pribadi, pikiran dan hati nurani, hak beragama, hak untuk tidak diperbudak, hak untuk diakui sebagai pribadi dan persamaan di hadapan hukum, dan hak untuk tidak dituntut atas dasar hukum yang berlaku surut adalah hak hak manusia yang tidak dapat dikurangi dalam keadaan keadaan apapun dan oleh siapapun. Namun pidana mati diperlukan pula sebagai upaya mencegah terjadinya kejahatan kejahatan khususnya yang tergolong berat. 


\section{Kesimpulan}

Berdasarkan pembahasan diatas maka dapat diperoleh kesimpulan dan saran yaitu

1. Pengaturan Pidana Mati di dalam Kitab Undang-Undang Hukum Pidana yaitu dalam Pasal 104 KUHP , Pasal 111 Ayat (2) KUHP , Pasal 124 Ayat (3) KUHP, Pasal 140 Ayat (3) KUHP ,Pasal 340 ,Pasal 365 Ayat (4) KUHP ,Pasal 368 Ayat (2) KUHP dan Pasal 444 KUHP .

2. Keberdaan pidana mati dalam sistem hukum di Indonesia di tinjau dalam perspektif HAM yaitu tentu akan bertentangan dengan HAM khususnya hak untuk hidup, Namun pidana mati diperlukan pula sebagai upaya mencegah terjadinya kejahatan -kejahatan khususnya yang tergolong berat.

\section{Saran}

Sebaiknya khususnya para penegak hukum di Indonesia harus lebih berani dalam mengambil keputusan tentang penjatuhan pidana mati terhadap pelaku kejahatan mengingat asas kepastian hukum yaitu suatu jaminan bahwa suatu hukum harus dijalankan dengan cara baik dan tepat. Kepastian hukum merupakan tujuan utama dari hukum dan kepastian hukum akan mengarahkan masyarakat bersikap positif pada hukum Negara yang telah ditentukan.

\section{Daftar Pustaka}

Buku :
Martiman Prodjohamidjojo, 1997, Memahami Dasar- Dasar Hukum Pidana Indonesia, PT Pradnya Paramita, Jakarta

Andrey Sujatmoko, 2007, Hukum HAM Dan Hukum Humaniter, Raja Grafindo Persada, Jakarta, Roeslan Saleh, 1978, Masalah Pidana Mati, Aksara Baru, Jakarta

Philip Nonet dan Philip Selznick, 2007, Hukum Responsif, Nusamedia, Bandung.

Wirjono Prodjodikoro, 2011, AsasAsas Hukum Pidana di Indonesia, Cet. IV, Refika Aditama, Bandung

Peraturan Perundang-Undangan :

Undang - undang Dasar Negara Republik Indonesia Tahun 1945

KUHP

Undang-Undang No.39 tahun 1999 tentang HAM 